\title{
ECOLOGY OF Cyprinus carpio var. specularis (PHYSICO-CHEMICAL CONDITIONS OF THE HABITAT)
}

\author{
M R Manon ${ }^{1}$ and M D Hossain ${ }^{2}$
}

\begin{abstract}
The study was carried out from November 2010 to August 2011. The study was conducted on the Atrai river, a flood plain and a culturable pond of Naogaon district for the find out of ecology of Cyprinus carpio var. specularis. The mean values of air temperature of Atrai river, flood plain and pond was 28.17. The mean values of water temperature of Atrai river, flood plain and pond was 26.39, 26.61 and $25.81^{\circ} \mathrm{C}$, respectively. The mean values of water transparency of Atrai river, flood plain and pond was 57.25, 47.20 and $41.32 \mathrm{~cm}$, respectively. The mean values of rainfall of Atrai river, flood plain and pond was 121.19. The mean values of $\mathrm{pH}$ of Atrai river, flood plain and pond was 8.03, 7.91 and 7.73, respectively. The mean values of DO of Atrai river, flood plain and pond was 5.99, 6.43 and $5.93 \mathrm{mg} / \mathrm{l}$, respectively. The mean values of $\mathrm{CO}_{2}$ of Atrai river, flood plain and pond was 6.87, 6.87 and $6.77 \mathrm{mg} / \mathrm{l}$, respectively.
\end{abstract}

Keywords: Ecology, Eco-Biology, Physical condition, Chemical condition, Physico-chemical parameters.

\section{INTRODUCTION}

Productivity and availability of fish depend on the physico-chemical conditions of the water bodies. Different environmental factors, which determine the characters of water, have a great role on the growth, maturity, reproduction and development of fish. Fishes are more depend on water temperature, turbidity, $\mathrm{pH}$, dissolved oxygen, free carbon dioxide, alkalinity, total hardness and ammonia for growth and development. Any changes of these parameters may affect the growth, development and maturity of fish. Proper management for obtaining optimum fish yield depends upon water quality parameters, because these parameters influence the aquatic production that is why fish culturists are more conscious about the maintenance of optimum condition of water quality parameters. But in case of the beel physico-chemical condition depend on natural process.

According to Rahman (1992), pond should not be shallower than one meter and deeper than five meter and the optimum depth should be two meter. Fish is poikilothermous. So, growth, reproduction and other biological activities of fish are controlled by temperature. For $1{ }^{\circ} \mathrm{C}$ rise of water temperature metabolic rate of fish increases $10 \%$. Water temperature is directly and closely related with air temperature but sometimes exceptions may occur when water temperature may be slightly higher than air temperature. Temperature has different relations with other factors especially dissolved oxygen content. Turbidity is a very important factor to be considered in fish culture. 26,000 ppm or more is considered lethal to fishes. In hot summer in a shallow water body

\footnotetext{
${ }^{1}$ Lecturer (Zoology), Niamotpur Degree College, Naogaon.

${ }^{2}$ Associate Professor, Department of Fisheries, University of Rajshahi, Rajshahi.
} 
(depth less than 1 meter) reduction of dissolved oxygen due to high temperature makes critical condition for fish. With the rise of temperature, bacterial decomposition increases.

High amount of free carbon dioxide is associated with low concentration of dissolved oxygen. Free $\mathrm{CO}_{2}$ more than $20 \mathrm{ppm}$ may be harmful to fishes and even lower concentrations may be equally harmful when dissolved oxygen concentrations are less than 3 to 5 ppm (Lagler, 1972). The circumstance neutral $\mathrm{pH}$ or slightly alkaline $\mathrm{pH}$ is most suitable for fish culture. Ammonia as $\mathrm{NH}_{4} \mathrm{OH}$ is toxic to fishes but ionic ammonia $\left(\mathrm{NH}_{4}{ }^{+}\right)$is not toxic. The toxicity of $\mathrm{NH}_{4} \mathrm{OH}$ varies with $\mathrm{pH}$, temperature, dissolved oxygen, etc. Total hardness and alkalinity are expressed as $\mathrm{CaCO}_{3}$ but they are not same thing, total hardness means the cation concentration and alkalinity means the anion concentration. Hardness mainly means the concentration of calcium and magnesium ions.

In this study it has been observed that the open water are polluted due to the run off water carrying residues of agricultural chemicals like pesticides, herbicides, insecticides and other domestic wastes as well as fertilizers used. Water quality is the suitability of water for the survival and growth of fish and it is normally governed by only a few variables (Boyd, 1992). Temperature, dissolved oxygen, $\mathrm{CO}_{2}, \mathrm{pH}$, hardness and ammonia are quite different their previous environment it can causes severe stress. Environmental stress is associated with opportunistic infections such as fungal, bacterial and ectoparasitic protozoa, which take advantage of the stressed host fish. So the water quality parameter is the most important factor for the aquatic environment.

\section{MATERIALS AND METHODS}

The study was conducted on the Atrai river, a flood plain and a culturable pond of Naogaon district. Water samples were collected twice in a month and collected from the depth of 20-35 cm below the surface at the time of 10:00 A.M.-12:00 P.M Water samples were collected with the help of a glass-stoppered bottle wrapping with black paper. After collection samples were brought to the Fisheries Research Laboratory, Department of Fisheries, University of Rajshahi, Rajshahi. Chemical analyses were also done immediate after arrival.

\section{Physical parameters}

The maximum and minimum air temperature, rainfall, humidity and rainy day were obtained from Bangladesh Meteorological Department, Regional Station, Rajshahi. The researcher physically visited the Meteorological Regional Station, Rajshahi and collected the data from the authority. The raw data were recorded daily basis and were supplied to the researcher.

Water temperature: A centigrade thermometer with a range of $0^{\circ} \mathrm{C}$ to $110^{\circ} \mathrm{C}$ was used to measure the water temperature at the time of sample collection.

Water transparency: Transparency was the measurement of limit of visibility. Transparency was measured by Secchi disc. It was expressed in $\mathrm{cm}$. 


\section{Chemical parameters}

The chemical parameters of the pond water viz. dissolved oxygen (DO), free carbon dioxide $\left(\mathrm{CO}_{2}\right)$ were analyzed by HACH Test Kit (Model FF-1A) in the Fisheries Research Laboratory of Department of Fisheries, University of Rajshahi, Rajshahi.

Hydrogen ion concentration (pH): The $\mathrm{pH}$ value of pond water was measured by digital pocket $\mathrm{pH}$ meter and titration method.

\section{Statistical analysis}

The statistical analysis of different meteorological and physico-chemical parameters was carried out. Only simple analysis viz. mean, standard deviation, simple line and bar graph are presented in this chapter.

\section{RESULTS AND DISCUSSION}

The physico-chemical conditions of the river Atrai, flood plain (Andasura beel) area and a pond exhibit more or less variation according to the changes of month and seasons.

\section{Physical parameters}

\section{Air Temperature}

Air temperature varied considerably throughout the year. The mean values of average day night maximum and minimum air temperature of the river Atrai, flood plain area and pond were recorded as $37.10^{\circ} \mathrm{C}$ in July and $16.13^{\circ} \mathrm{C}$ in January. The mean value of air temperature was recorded as $28.17^{\circ} \mathrm{C}$ (Table 1$)$.

\section{Water Temperature}

The water temperature of the sampling area showed considerable variation throughout the year. The water temperature fluctuated due to the cause of more or less sunny or rainfall condition. The mean values of monthly maximum and minimum water temperature of the river Atrai were found to vary from $36.22^{\circ} \mathrm{C}$ in July to $13.17^{\circ} \mathrm{C}$ in January. The mean value of water temperature was recorded as $26.39^{\circ} \mathrm{C}$ (Table-1 and Fig. 1).

In floodplain area (Andasura beel) the maximum and minimum water temperature were found as $36.22^{\circ} \mathrm{C}$ in July and $15.17^{\circ} \mathrm{C}$ in January. The mean value of water temperature was recorded as $26.61^{\circ} \mathrm{C}$. In the pond the maximum and minimum water temperature were found as $35.22^{\circ} \mathrm{C}$ in July and $14.17^{\circ} \mathrm{C}$ in January. The mean value of water temperature was recorded as $25.81^{\circ} \mathrm{C}$ (Table-1 and Fig. 1).

The present observation reveals that the annual air temperature cycle maintained a close parallel relationship with annual cycle of water temperature. The temperature of all the studied water 
bodies usually declined from November and reached the minimum in January and there after increased steadily reaching the maximum during April to July in the river Atrai, flood plain area and pond. Differences between air temperature and water temperature are higher during winter and lower in summer, the occurrence of the temperature curve of air and water coincided each other during monsoon / flood season due to sudden fall of air temperature in comparison to the water temperature followed by the heavy rainfall.

\section{Water Transparency}

In the river Atrai, the monthly mean values of water transparency exhibited the maximum $90 \mathrm{~cm}$ in October and the minimum $26 \mathrm{~cm}$ in June. The mean value was recorded as $57.25 \mathrm{~cm}$. In the flood plain area the monthly mean values of water transparency exhibited the maximum $99 \mathrm{~cm}$ in January and the minimum $17 \mathrm{~cm}$ in August. The mean value of water transparency of flood plain was recorded as $47.20 \mathrm{~cm}$. In the pond the maximum and minimum water transparency were recorded as $67 \mathrm{~cm}$ in January and $17 \mathrm{~cm}$ in August. The mean value of water transparency was recorded as $41.32 \mathrm{~cm}$ (Table-1 and Fig. 1).

Water transparency of the studied water bodies was low value due to greatest turbidity. The turbidity of water is generally due to the suspended inorganic substances and planktonic organisms present in water. According to Jhingran (1983), turbidity due to profusion of plankton is an indication of high fertility but that caused by silt or mud beyond a limit, is harmful to fish and other organisms. In the river Atrai, the minimum values of transparency are found in the monsoon and post monsoon months like June to September due to strong current of water which washed away huge silt in water including many other suspended matters. Lakshminarayana (1965) and Hickman (1979) also made such type of observation.

\section{Rainfall}

In the study area there were rainfalls more or less all the year round. Usually in the winter season rainfall is occasional but in the monsoon or summer season there were frequent and heavy rainfalls with gusty wind. In Naogaon the maximum rainfall $275.07 \mathrm{~mm}$ was recorded in the month of August while the minimum rainfall about $0.00 \mathrm{~mm}$ was recorded in the month of January. The mean value of rainfall was recorded as $121.19 \mathrm{~mm}$ (Table-1). There is more or less rainfall all the year round. Like other hydrological features rainfall is governed by the monsoon (Mahmood, 1986; Rahman, 1989). The rainfall is also an important ecological factor for aquatic environment. 
Table 1: The mean values (mean \pm sd) of different physical and chemical parameters of the River, Flood plain and pond at Naogaon

\begin{tabular}{|c|c|c|c|c|c|c|c|}
\hline \multirow{2}{*}{$\begin{array}{c}\text { Study } \\
\text { site }\end{array}$} & \multicolumn{4}{|c|}{ Physical parameters } & \multicolumn{3}{|c|}{ Chemical parameters } \\
\hline & $\begin{array}{c}\text { Air temperature } \\
\left({ }^{\circ} \mathrm{C}\right)\end{array}$ & $\begin{array}{c}\text { Water } \\
\text { temperature }\left({ }^{\circ} \mathrm{C}\right)\end{array}$ & $\begin{array}{c}\text { Water } \\
\text { transparency }(\mathbf{c m})\end{array}$ & $\begin{array}{c}\text { Rainfall } \\
\text { (mm) }\end{array}$ & pH & $\begin{array}{c}\text { DO } \\
(\mathrm{mg} / \mathrm{l})\end{array}$ & $\begin{array}{c}\mathrm{CO}_{2} \\
(\mathrm{mg} / \mathrm{l})\end{array}$ \\
\hline River & $28.17 \pm 6.51$ & $26.39 \pm 7.11$ & $57.25 \pm 1.90$ & $\begin{array}{l}121.19 \pm \\
112.61\end{array}$ & $8.03 \pm 0.32$ & $5.99 \pm 0.78$ & $6.87 \pm 1.72$ \\
\hline $\begin{array}{l}\text { Flood } \\
\text { plain }\end{array}$ & $28.17 \pm 6.51$ & $26.61 \pm 6.51$ & $47.20 \pm 2.32$ & $\begin{array}{l}121.19 \pm \\
112.61\end{array}$ & $7.91 \pm 0.71$ & $6.43 \pm 0.77$ & $6.87 \pm 1.89$ \\
\hline Pond & $28.17 \pm 6.51$ & $25.81 \pm 7.31$ & $41.32 \pm 1.75$ & $\begin{array}{l}121.19 \\
\pm 112.61\end{array}$ & $7.73 \pm 0.49$ & $5.93 \pm 0.77$ & $6.77 \pm 1.87$ \\
\hline
\end{tabular}

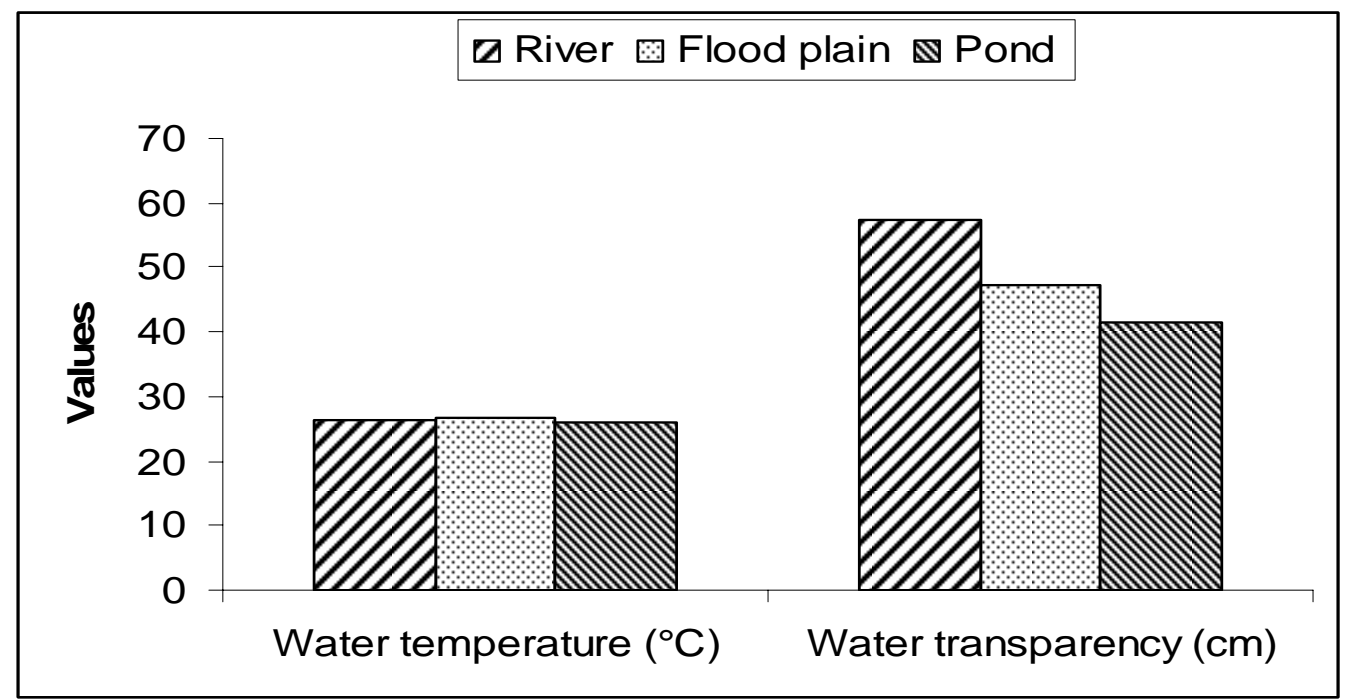

Fig. 1: Variations in the mean values of physical parameters of three study site Chemical parameters

\section{Hydrogen Ion Concentration (pH)}

The maximum and minimum mean values of $\mathrm{pH}$ were recorded as 8.92 in May and 7.75 in March. The mean value of $\mathrm{pH}$ was recorded as 8.03. In the flood plain area the maximum and minimum monthly mean values of $\mathrm{pH}$ were recorded as 9.07 in November and 6.99 in September. The mean value of $\mathrm{pH}$ was recorded as 7.91. In the pond the maximum and minimum monthly mean values of $\mathrm{pH}$ were recorded as 8.01 in December and 6.92 in May. The mean value of $\mathrm{pH}$ was recorded as 7.73 (Table-1 and Fig. 2). These values are also indicating neutral or slightly alkaline nature of water and all water body are suitable habitat for the fish. Ehsan et al. (1997) recorded the values of $\mathrm{pH}$ of water of Halti beel ranged between 7.1 to 8.03. In our Bangladesh $\mathrm{pH}$ values were recorded in some running water system by Islam et al. (1974) as maximum 7.8 (July) and minimum 6.9 (March) in the river Buriganga and by Patra. 


\section{Dissolved Oxygen (DO)}

In the river Atrai the maximum and minimum monthly mean values of DO content were recorded as $7.10 \mathrm{mg} / \mathrm{l}$ in January and $5.21 \mathrm{mg} / \mathrm{l}$ in August. The mean value of DO was recorded as 5.99 $\mathrm{mg} / \mathrm{l}$. For the flood plain area the maximum and minimum monthly DO were recorded as 8.02 $\mathrm{mg} / \mathrm{l}$ in October and $5.10 \mathrm{mg} / \mathrm{l}$ in September. The mean value of DO was recorded as $6.43 \mathrm{mg} / \mathrm{l}$. In the pond the maximum and minimum monthly mean values of monthly DO were recorded as 7.10 $\mathrm{mg} / \mathrm{l}$ in January and $4.21 \mathrm{mg} / \mathrm{l}$ in August. The mean value of DO was recorded as $5.93 \mathrm{mg} / \mathrm{l}$ (Table-1 and Fig. 2). In flood plain area DO contents increase gradually from September reaching the maximum in December-January and then decrease in July to August. Similar observation was recorded by George (1964), Vas and Kumar (1968) in Indra Sagar Tank, India. Higher values of DO in winter were possibly due to low temperature and low rainfall. Ehshan et al. (1997) reported maximum dissolved oxygen in January whereas minimum in June in Halti beel. In pond the DO contents increase in the months of September to February and decrease in July to August. The same result was noticed by Islam and Mendes (1976). Ali et al. (1989) found high value of DO during winter and low value in summer.

\section{Free Carbon Dioxide $\left(\mathrm{CO}_{2}\right)$}

In the river Atrai the maximum and minimum monthly mean values of $\mathrm{CO}_{2}$ were recorded as 9.10 $\mathrm{mg} / \mathrm{l}$ in September and $4.10 \mathrm{mg} / \mathrm{l}$ in February. The mean value of $\mathrm{CO}_{2}$ was recorded as $6.87 \mathrm{mg} / \mathrm{l}$. In the flood plain area the maximum and minimum monthly mean values of $\mathrm{CO}_{2}$ were recorded as $9.10 \mathrm{mg} / \mathrm{l}$ in September and $4.10 \mathrm{mg} / \mathrm{l}$ in February. The mean value of $\mathrm{CO}_{2}$ was recorded as 6.87 $\mathrm{mg} / \mathrm{l}$. In the pond the maximum and minimum monthly mean values of $\mathrm{CO}_{2}$ were recorded as 9.08 $\mathrm{mg} / \mathrm{l}$ in July and $4.10 \mathrm{mg} / \mathrm{l}$ in February. The mean value of $\mathrm{CO}_{2}$ was recorded as $6.77 \mathrm{mg} / \mathrm{l}$ (Table1 and Fig. 2).

The free $\mathrm{CO}_{2}$ content of the river, beel and pond showed seasonal changes which increased during summer and autumn and decreased during winter and spring. Islam and Mendes (1976) was observed similar results in Bangladesh.

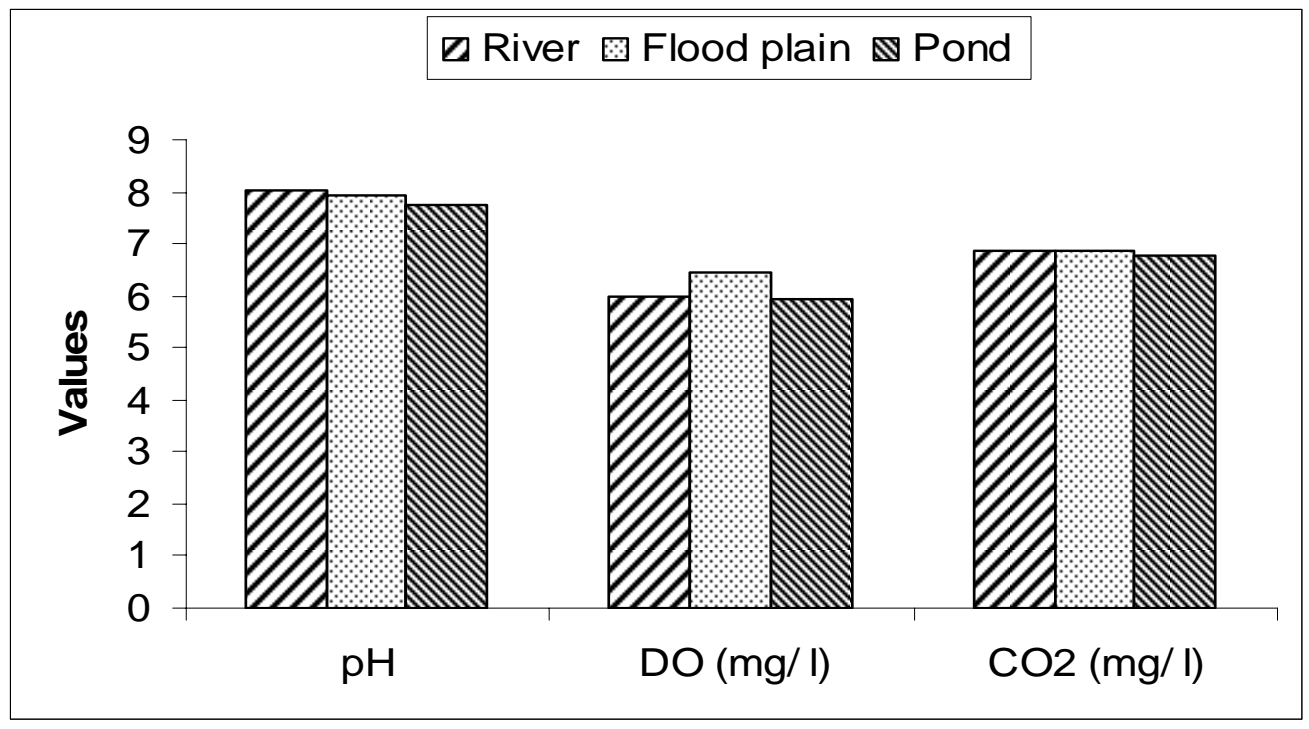

Fig. 2: Variations in the mean values of chemical parameters of three study site 


\section{REFERENCES}

Ali, S., Chowdhury, A. H., Chowdhury, D. R. and Begum, S. 1989. Studies on seasonal variations of physico-chemical and biological conditions in a pond. Dhaka University Studies Part E. 4(2):113-123.

Boyd, C. E. 1992. Water quality management for pond fish culture. Vol. 9. pp.388.

Ehshan, M. A., Hossain, M. S., Razzaque, A., Mollah, M. F. A. and Mazid, M. A. 1997. Limnology of a flood plain: Halti Beel. Univ. J. Zool . Rajshahi Univ. Vol. 16: pp. 95-98.

George, M. G. 1964. Comparative plankton ecology of five fish tanks in New Delhi. India. Hydrobiologia. 27: 81-108.

Hickman, M. 1979. Seasonal succession, standing crop and determinants of the phytoplankton of Ministik lake Alberta, Canada. Hydrobiologia. 64:105-121.

Islam, A. K. M. N. and Mendes, F. 1976. Limnological studies of Jheel in Sher-E-Bangla Nagar, Dhaka. Dhaka Univ. Stud. B. 24(2): 63-71.

Islam, M. A., Chowdhury, M. Y. and Karim, P. K. 1974 . A comparative study of some physicochemical factors and the growth of major carps in ponds. Bangladesh J. Aq. Cul. No. 1(1):61-73.

Jhingran, V. G. 1983. Fish and Fisheries of India (Revised and enlarged $2^{\text {nd }}$ ed). Hindustan Publishing Corporation (India) Delhi. p 645.

Lagler, K. F. 1972. Freshwater Fishery Biology. 2nd ed. W. M. C. Brown Company Publishers, Dubuque, Iowa. 421 pp.

Lakshminarayana, J. S. S. 1965. Studies on the phytoplankton of the river Ganges, Varanashi, India, Part-1 and 2. Hydrobiologia. 25:(1-2):119-164.1

Mahmood, N. 1986. Hydrobiology of the Kaptai Reservoir. Final report on the Kaptai Reservoir Studies Program. FAO/UNDP Aquaculture Development and Coordination Programs, Rome, Italy. Contract No. DP/BGD/615-4.

Rahman, A. K. A. 1989. Freshwater Fishes of Bangladesh. The Zoological Society of Bangladesh, Department of Zoology, University of Dhaka, Dhaka-1000. 364p.

Rahman, M. S. 1992. Water Quality Management in Aquaculture. BRAC Prokashana, Dhaka, Bangladesh. p 84.

Vas, L. N. and Kumar, H. D. 1968. Studies on the phytoplankton and other algae of Indrasagar tank Udaipur, India, Hydrobiologia, 27: 529-547. 